\title{
RESPON TANAMAN KENTANG (Solanum tuberosum L.) PADA BERBAGAI KETEBALAN MEDIA COCOPEAT DAN WAKTU PEMBERIAN NUTRISI SUNDSTROM
}

\author{
FAJRIN PRAMANA PUTRA ${ }^{1 *}$, SAPARSO $^{2}$, SLAMET ROHADI $^{2}$, DAN RONI \\ ISMOYOJATI $^{1}$ \\ ${ }^{1}$ Program Studi Teknologi Produksi Tanaman Perkebunan, Politeknik Lamandau, Lamandau \\ ${ }^{2}$ Program Studi Agroteknologi, Fakultas Pertanian, Universitas Jenderal Soedirman, Purwokerto \\ e-mail: fajrin.pramana.p@gmail.com
}

\begin{abstract}
ABSTRAK
Penelitian ini bertujuan untuk mengetahui pertumbuhan dan hasil umbi kentang (G0) pada ketebalan media cocopeat dan waktu pemberian larutan nutrisi yang berbeda. Penelitian ini dilakukan dalam screen house di Desa Pandansari, Kecamatan Paguyangan dari bulan Oktober 2014 sampai Januari 2015. Penelitian menggunakan Rancangan Acak Kelompok Lengkap dengan 2 faktor dan 3 ulangan. Faktor pertama adalah ketebalan media dengan tiga taraf, yakni $10 \mathrm{~cm}, 15 \mathrm{~cm}$, dan $20 \mathrm{~cm}$. Faktor kedua adalah waktu pemberian nutrisi dengan dua taraf, yakni 3 hari sekali dan 6 hari sekali. Hasil penelitian menunjukkan bahwa ketebalan media $20 \mathrm{~cm}$ memberikan pertumbuhan yang baik pada tinggi tanaman, jumlah daun, luas daun tanaman dan dapat meningkatkan panjang akar hingga 23.67 $\%$. Waktu pemberian nutrisi 3 hari sekali memberikan pertumbuhan yang baik pada tinggi tanaman, jumlah daun, luas daun, bobot tanaman segar, bobot tanaman kering, dan hasil yang baik pada efektifitas stolon (49.84 \%), bobot umbi segar (137.85 g), dan bobot umbi kering (21.55 g). Perlakuan ketebalan media cocopeat dan waktu pemberian nutrisi belum mampu memberikan peningkatan produksi umbi kentang (G0).
\end{abstract}

Kata kunci : cocopeat, kentang, ketebalan media, waktu pemberian nutrisi

\begin{abstract}
This research purposes know the growth and tubers yield of potato $(G 0)$ under various thickness of cocopeat media and time of sundstrom nutrient giving. The research was carried in the screen house in Pandansari, Paguyangan district from October 2014 until January 2015. The research used Randomized Complete Block Design with 2 factor and 3 repetitions. The first factor was the thickness of media with three levels; $10 \mathrm{~cm}, 15 \mathrm{~cm}$, and $20 \mathrm{~cm}$. The second factor was the time of nutrient solution giving with two levels; once for three days and once for six days. The results of the research showed that the thickness of cocopeat media $20 \mathrm{~cm}$ was good for plant height, total of leaves, wide of plant leaves, and improve the roots length $23.6 \%$. Time of nutrient giving once for three days was good for plant height, total of leaves, wide of plant leaves, weight of fresh plant, weight of dry plant and the result was good for stolon effectiveness (49.84\%), weight of fresh tuber (137.85 g), and weight of dry tuber $(21.55 \mathrm{~g})$. The treatment of cocopeat medium thickness and time of nutrient giving had not been able to provide increased yield of potato tuber $(G 0)$.
\end{abstract}

Key words : cocopeat, media thickness, potato, time of nutrient giving

Diterima: 29 Agustus 2018: disetujui 27 September 2018

\section{PENDAHULUAN}

Kentang merupakan salah satu tanaman kembangkan di Indonesia karena sering umbi yang mendapat prioritas untuk di dimanfaatkan untuk berbagai kebutuhan 
sehari-hari. Tanaman ini memiliki potensi untuk dikembangkan dalam mendukung program diversifikasi pangan (Prahardini et al., 2008). Tanaman kentang dijadikan salah satu komoditas pendukung program diversifikasi pangan dikarenakan mempunyai kandungan protein tinggi. Protein pada kentang mampu memberikan gizi yang baik bagi orang dewasa (Kenneth dan Ornelas, 2012).

Produksi kentang di Indonesia pada tahun 2012 adalah 1.09 juta ton dengan ratarata produktivitas mencapai 16.58 ton/ha, sedangkan pada tahun 2013 adalah 1.12 juta ton dengan rata-rata produktivitas mencapai 16.02 ton/ha (Badan Pusat Statistik, 2014). Meskipun pada tahun 2013 hasil produksi kentang di indonesia naik 30.042 ton, akan tetapi produktivitas kentang menurun 0.56 ton/ha. Penurunan produktivitas kentang ini disebabkan karena banyak faktor. Penggunaan benih kentang yang kurang berkualitas, dan ketersediaan benih pada waktu akan digunakan menjadi salah satu penyebab turunnya produktivitas, karena petani akan menggunakan umbi kentang yang dihasilkan dari hasil budidaya (Sayaka dan Hestina, 2011). Ketersediaan benih kentang bersertifikat yang sedikit, sehingga membuat petani memilih menyisihkan sebagian hasil panen untuk benih musim tanam berikutnya.

Usaha untuk meningkatkan produksi benih kentang berkualitas semakin gencar dilakukan oleh para peneliti kentang. Hasil produksi kentang yang maksimal, bisa didapatkan dengan menggunakan benih yang berkualitas dalam proses budidayanya. Salah satu usaha yang dilakukan oleh para peneliti adalah dengan penyediaan benih kentang G0 yang bebas dari penyakit dengan berbagai teknologi. Salah satu teknologi yang mulai dikembangkan adalah budidaya system screen dengan media steril cocopeat sebagai upaya memanfaatkan potensi sumberdaya lokal sebagai media tanam pembibitan kentang G0. Teknologi budidaya kentang system screen dengan media steril cocopeat mampu menghasilkan 3-4 knol per tanaman (Suwarno, 2008).

Cocopeat merupakan limbah pengolahan sabut kelapa yang memiliki daya serap air dan Kandungan Trichoderma molds-nya menghasilkan enzim yang dapat mengurangi penyakit dalam tanah (Kristijono, 2010). Keberhasilan dalam budidaya kentang untuk benih tidak hanya ditentukan dari media tanamnya saja, tetapi faktor penentuan waktu pemberian nutrisi juga berpengaruh dalam produksi umbi kentang. Zamami et al. (2016) menjelaskan bahwa pemberian nutrisi pada tanaman dapat mempengaruhi pertumbuhan dan perkembangan tanaman Penelitian ini bertujuan untuk mengetahui pertumbuhan dan hasil umbi kentang (G0) pada ketebalan media cocopeat dan waktu pemberian larutan nutrisi yang berbeda.

\section{METODE PENELITIAN}

Penelitian dilaksanakkan di screen house Desa Pandansari, Kecamatan Paguyangan, Kabupaten Brebes dengan ketinggian tempat $1200 \mathrm{~m}$ dpl, Laboratorium Agronomi dan Hortikultura, dan Laboratorium Tanah/Sumber Daya Lahan Fakultas Pertanian UNSOED. Penelitian dimulai dari bulan Oktober 2014 sampai Januari 2015.

Bahan yang digunakan dalam penelitian adalah bibit stek batang tanaman kentang varietas Tedjo MZ hasil kultur jaringan dari Balai Penelitian Tanaman Sayur (Balitsa), cocopeat sebagai media tanam, nutrisi Sundstrom 2000 ppm dengan $\mathrm{pH}$ 5.5-6.5 (Kandungan nutrisi Sundstrom adalah $32 \%$ kalsium amonium nitrat, $17 \%$ kalium nitrat, $12 \%$ monokalium dihidro fosfat, $3 \%$ amonium sulfat, $5 \%$ kalium sulfat, $30 \%$ magnesium sulfat, dan $1 \%$ unsur hara mikro (Mn, Zn, Fe-EDTA, B, dan Mo)) (Ginting et al., 2008), pupuk Petroganik 100 $\mathrm{g} / \mathrm{m}^{2}$ sebagai pupuk dasar. Alat yang digunakan dalam penelitian adalah Screen 
house, bak untuk bedengan berukuran $2 \mathrm{~m}^{2}$ per kombinasi perlakuan, $\mathrm{pH}$ meter digital Pen Type PH-009, dan TDS meter tipe TDS3.

Penelitian ini berupa percobaan di dalam screen house dengan rancangan perlakuan faktorial $3 \times 2$. Faktor pertama adalah ketebalan media steril cocopeat dengan tiga taraf, yakni $10 \mathrm{~cm}(\mathrm{~K} 1), 15 \mathrm{~cm}$ (K2), dan $20 \mathrm{~cm}$ (K3), sedangkan faktor kedua adalah waktu pemberian larutan nutrisi Sundstrom dengan 2 taraf, yakni 3 hari sekali (F1) dan 6 hari sekali (F2). Semua kombinasi perlakuan dialokasikan ke dalam rancangan lingkungan Rancangan Acak Kelompok Lengkap (RAKL) dengan 3 ulangan. Data yang diperoleh dianalisis dengan ANOVA sesuai dengan rancangan acak kelompok lengkap (RAKL) menggunakan Ms. Excel macro add-ins DSAASTAT (Onofri dan Pannuci, 2014). Apabila data hasil Anova berbeda secara nyata, dilanjutkan dengan uji DMRT pada tingkat $5 \%$.

Tabel 1. Sifat fisik dan kimia media steril cocopeat hasil uji laboratorium

\begin{tabular}{lcc}
\hline \multicolumn{1}{c}{ Parameter } & Hasil Uji Laboratorium & Harkat \\
\hline $\mathrm{pH}$ & 5.30 & Masam \\
$\mathrm{P}_{2} \mathrm{O}_{5}$ Tersedia (ppm) & 644.10 & Sangat Tinggi \\
Kadar Air Kapasitas Lapang (\%) & 86.99 & Sangat Tinggi \\
$\mathrm{KTK}(\mathrm{me} \%)$ & 84.26 & Sangat Tinggi \\
\hline
\end{tabular}

Pengharkatan menurut Pusat Penelitian Tanah (1983) dalam Hardjowigeno (2010)

\section{HASIL DAN PEMBAHASAN}

Sifat kimia dan fisik dari media steril cocopeat yang digunakan untuk penelitian disajikan pada Tabel 1. Hasil analisis ragam data pengamatan pertumbuhan dan hasil tanaman kentang pada berbagai ketebalan media steril cocopeat dan waktu pemberian nutrisi disajikan pada Tabel 2 dan 3 .

\section{Pertumbuhan Tanaman Kentang Pada Ketebalan Media Steril Cocopeat}

Ketebalan media tanam berpengaruh linear positif terhadap panjang akar yaitu $Y=$ $0.29 \mathrm{X}+8.96\left(\mathrm{R}^{2}=0.89\right)$, karena dari ketiga perlakuan ketebalan terjadi peningkatan pertumbuhan panjang akar (Gambar 1). Panjang akar tanaman kentang terpanjang diperoleh pada unit percobaan dengan menggunakan ketebalan media cocopeat 20 $\mathrm{cm}$ sebesar $14.99 \mathrm{~cm}$ dibandingkan dengan ketebalan media $15 \mathrm{~cm}$ dan $10 \mathrm{~cm}$ yang masing-masing sebesar $12.67 \mathrm{~cm}$ dan 12.12 $\mathrm{cm}$ (Tabel 2). Dari data pertumbuhan panjang akar tersebut menunjukkan bahwa ketebalan media $20 \mathrm{~cm}$ mampu meningkatkan panjang akar sebesar $23.67 \%$. Ketebalan media tanam berpengaruh linear positif terhadap tinggi tanaman (Gambar 1). Ketebalan media tanam memberikan pengaruh terhadap tinggi tanaman dengan persamaan $\hat{Y}=0.81 X+32.34\left(\mathrm{R}^{2}=0.98\right)$. Ketebalan media tanam berpengaruh linear positif terhadap jumlah daun dan luas daun tanaman (Gambar 1). Ketebalan media tanam memberikan pengaruh pada jumlah daun dengan persamaan $Y=2.66 X+41.74$ $\left(\mathrm{R}^{2}=0.99\right)$. Dan memberikan pengaruh pada luas daun tanaman dengan persamaan $Y=$ 195.53X + $1982.6\left(\mathrm{R}^{2}=0.99\right)$.

Ketebalan media berkaitan dengan ruang yang diberikan suatu media untuk pertumbuhan akar. Ketebalan yang semakin dalam dapat merangsang akar untuk melakukan penetrasi sampai dasar media. Menurut Ginting (2009) ketebalan media tanam yang semakin tinggi akan meningkatkan panjang akar tanaman, hal ini berkaitan dengan kemampuan akar untuk melakukan penetrasi sampai ke bagian dasar media untuk mendapatkan air dan hara.

Akar yang panjang pada ketebalan 20 $\mathrm{cm}$ mampu memaksimalkan penyerapan air dan mineral yang terdapat pada dasar media, sehingga pertumbuhan tajuk tanaman akan meningkat. Menurut Alwi et al. (2008) pertumbuhan panjang akar yang baik mampu memaksimalkan penyerapan air dan mineral 
didalam tanah, sehingga mampu meningkatkan pertumbuhan tajuk tanaman.

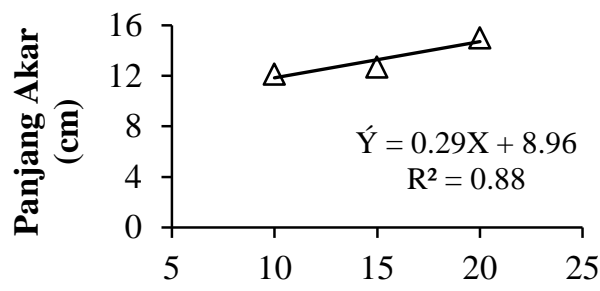

Ketebalan Media (cm)

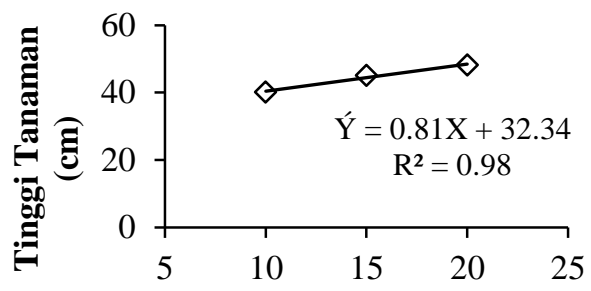

Ketebalan Media (cm)

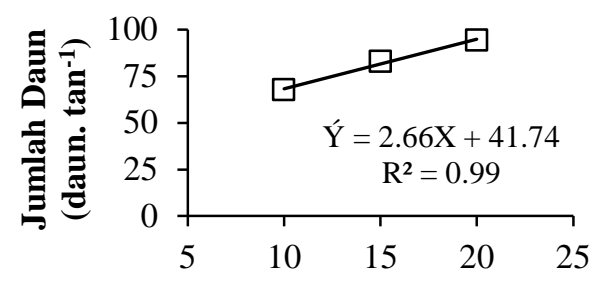

Ketebalan Media (cm)

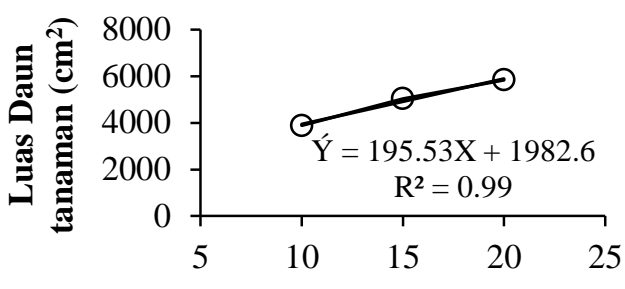

Ketebalan Media (cm)

Gambar 1. Respon pertumbuhan tanaman kentang pada berbagai ketebalan media cocopeat.

Pertumbuhan dan Hasil Tanaman Kentang pada Waktu Pemberian Nutrisi Sundstrom

"Waktu pemberian nutrisi memberikan pengaruh yang nyata $(\alpha=0.05)$ terhadap pertumbuhan dan hasil tanaman kentang, yaitu tinggi tanaman, jumlah daun, luas daun tanaman, bobot tanaman segar, bobot tanaman kering, efektivitas stolon, bobot umbi segar, dan bobot umbi kering. Gambar 4 menunjukkan perbedaan pertumbuhan tinggi tanaman, jumlah daun, dan luas daun tanaman pada waktu pemberian nutrisi. Waktu pemberian nutrisi 3 hari sekali memberikan pertumbuhan terbaik pada tinggi tanaman, jumlah daun, dan luas daun tanaman" sebesar $47.82 \mathrm{~cm}, 90.26$ daun. $\tan ^{-}$ 1, dan 5,613.14 $\mathrm{cm}^{2}$. Sedangkan waktu pemberian nutrisi 6 hari sekali memberikan pertumbuhan lebih rendah yaitu $41.03 \mathrm{~cm}$, 72.94 daun. $\tan ^{-1}$, dan 4,218.08 $\mathrm{cm}^{2}$. Pemberian nutrisi Sundtrom 3 hari sekali mampu memberikan hara yang cukup bagi pertumbuhan tanaman kentang.

Pertumbuhan biomasa (tinggi tanaman, jumlah daun, dan luas daun tanaman) yang baik pada pemberian nutrisi 3 hari sekali sejalan dengan bertambahnya bobot tanaman segar. Gambar 4 menunjukkan bahwa pemberian nutrisi 3 hari sekali mampu meningkatkan bobot tanaman segar sebesar $53.31 \%$. Bobot tanaman segar pada pemberian nutrisi 3 hari sekali sebesar 57.13 g, sedangkan bobot tanaman segar yang diberikan nutrisi 6 hari sekali hanya $37.51 \mathrm{~g}$.

Bobot kering suatu tanaman menggambarkan pertumbuhan tanaman. Gambar 4 menunjukkan perbedaan bobot tanaman kering pada waktu pemberian nutrisi. Bobot tanaman kering terbaik terdapat pada pemberian nutrisi 3 hari sekali yaitu $3.71 \mathrm{~g}$ sedangkan pada pemberian nutrisi 6 hari sekali hanya $2.00 \mathrm{~g}$. 


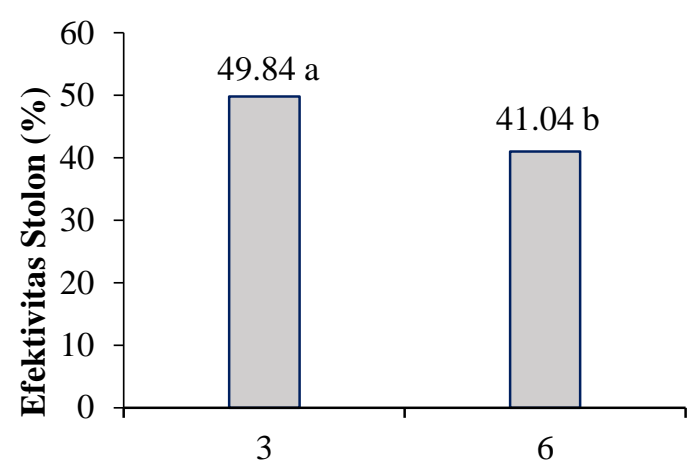

Waktu Pemberian Larutan Nutrisi

(Hari)

Gambar 2. Efektivitas stolon pada waktu pemberian larutan nutrisi Sundstrom.

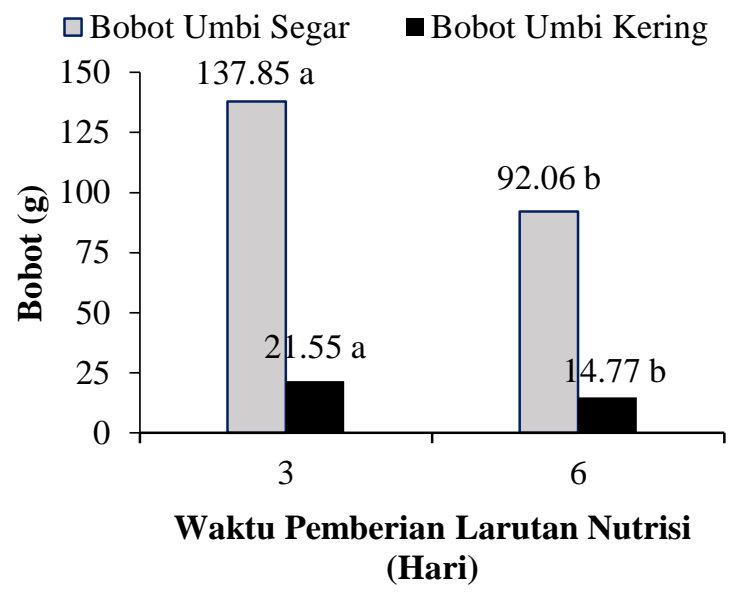

Gambar 3. Bobot umbi segar dan bobot umbi kering pada waktu pemberian larutan nutrisi Sundstrom.

Unsur hara makro dan mikro yang terdapat dalam pupuk terutama $\mathrm{N}$ dapat meningkatkan akumulasi bahan kering pada tanaman, terutama pada daun dan batang (Schuzle dan Cadwell, 1995; Ramiez et al., 2014). Peningkatan berat kering tanaman mencerminkan bahwa proses fotosintesis pada tanaman lebih baik, sehingga fotosintat yang dihasilkan dapat mencukupi kebutuhan tanaman untuk pertumbuhan dan perkembangannya (Zelalem et al., 2009). Gambar 2 dan 3 menunjukkan perbedaan hasil efektifitas stolon, bobot umbi segar, dan bobot umbi kering pada pemberian nutrisi 3 hari sekali dengan pemberian nutrisi 6 hari sekali. Pemberian nutrisi 3 hari sekali memberikan hasil yang baik pada efektifitas stolon, bobot umbi segar, dan bobot umbi kering sebesar $49.84 \%, 137.85 \mathrm{~g}$, dan 21.55 g. Efektifitas stolon menggambarkan jumlah stolon yang dapat membentuk umbi. Efektifitas stolon yang tinggi menunjukkan stolon yang membentuk umbi tinggi pula.
Efektifitas stolon yang tinggi dipengaruhi oleh pembentukkan karbohidrat dalam umbi.

Menurut Zelelew et al. (2016) pembentukkan karbohidrat dalam umbi dipengaruhi oleh unsur hara kalium. Hal ini diperkuat oleh El-Latif et al. (2011) bahwa unsur kalium diperlukan tanaman dalam sintesa protein dan karbohidrat serta translokasi karbohidrat yang lebih lancar. Pada proses fotosintesis Kalium memegang peranan penting, terutama pada prose bukaan stomata, sehingga fotosintesis akan optimum, dan senyawa organic yang menjadi kebutuhan tanaman akan terbentuk optimal (Napitupulu dan Winarto, 2010).

Penimbunan jumlah karbohidrat ke dalam umbi mempengaruhi bobot umbi segar dan kering. Semakin banyak karbohidrat yang dapat ditranslokasikan dalam umbi maka semakin meningkatkan bobot umbi. Bahan kering yang terakumulasi dalam umbi berupa karbohidrat, protein dan vitamin, dan 
bahan kering yang diakumulasi ini dihasilkan dari proses fotosintesis (Mobini et al., 2015).

Tabel 2. Variabel pertumbuhan tanaman kentang diberbagai ketebalan media cocopeat dan waktu pemberian nutrisi Sundstrom

\begin{tabular}{|c|c|c|c|c|c|}
\hline \multirow{3}{*}{ Perlakuan } & \multicolumn{5}{|c|}{ Variabel Pengamatan } \\
\hline & $\begin{array}{c}\text { Tinggi } \\
\text { Tanaman }(\mathbf{c m})\end{array}$ & $\begin{array}{c}\text { Jumlah Daun } \\
\left(\text { daun. } \tan ^{-1}\right)\end{array}$ & $\begin{array}{c}\text { Luas Daun } \\
\text { Tanaman }\left(\mathrm{cm}^{2}\right)\end{array}$ & $\begin{array}{c}\text { Jumlah } \\
\text { Akar (akar) }\end{array}$ & $\begin{array}{c}\text { Panjang Akar } \\
(\mathrm{cm})\end{array}$ \\
\hline & \multicolumn{5}{|c|}{ Ketebalan Media } \\
\hline K1 & $40.09 \mathrm{c}$ & $67.75 \mathrm{c}$ & $3877.55 \mathrm{c}$ & 39.39 & $12.12 \mathrm{~b}$ \\
\hline $\mathrm{K} 2$ & $45.03 \mathrm{~b}$ & $82.74 \mathrm{~b}$ & $5036.40 \mathrm{~b}$ & 34.17 & $12.67 \mathrm{~b}$ \\
\hline $\mathrm{K} 3$ & $48.15 \mathrm{a}$ & $94.32 \mathrm{a}$ & $5832.88 \mathrm{a}$ & 40.72 & $14.99 \mathrm{a}$ \\
\hline F hitung & 5.06 & 4.19 & 4.51 & 1.24 & 7.06 \\
\hline F tabel & 4.10 & 4.10 & 4.10 & 4.10 & 4.10 \\
\hline $\mathrm{CV}(\%)$ & 9.96 & 19.53 & 23.08 & 19.97 & 10.57 \\
\hline \multicolumn{6}{|c|}{ Frekuensi Pemberian Nutrisi } \\
\hline F1 & $47.82 \mathrm{a}$ & $90.26 \mathrm{a}$ & $5613.14 \mathrm{a}$ & 38.74 & $14.17 \mathrm{a}$ \\
\hline $\mathrm{F} 2$ & $41.03 \mathrm{~b}$ & $72.94 \mathrm{~b}$ & $4218.08 \mathrm{~b}$ & 37.44 & $12.35 \mathrm{~b}$ \\
\hline F hitung & 10.60 & 5.31 & 6.81 & 0.13 & 7.60 \\
\hline F tabel & 4.96 & 4.96 & 4.96 & 4.96 & 4.96 \\
\hline $\mathrm{CV}(\%)$ & 9.96 & 19.53 & 23.08 & 19.97 & 10.57 \\
\hline \multicolumn{6}{|c|}{ Kombinasi Perlakuan Ketebalan Media dan Frekuensi Pemberian Nutrisi } \\
\hline K1F1 & 40.07 & 68.33 & 3954.53 & $33.22 \mathrm{~b}$ & $12.11 \mathrm{c}$ \\
\hline $\mathrm{K} 1 \mathrm{~F} 2$ & 40.01 & 67.17 & 3800.57 & $45.56 \mathrm{a}$ & $12.13 \mathrm{c}$ \\
\hline $\mathrm{K} 2 \mathrm{~F} 1$ & 50.02 & 91.83 & 5852.64 & $34.33 \mathrm{~b}$ & $13.06 \mathrm{~b}$ \\
\hline $\mathrm{K} 2 \mathrm{~F} 2$ & 40.04 & 73.64 & 4220.16 & $34.00 \mathrm{~b}$ & $12.27 \mathrm{bc}$ \\
\hline $\mathrm{K} 3 \mathrm{~F} 1$ & 53.38 & 110.61 & 7032.26 & $48.67 \mathrm{a}$ & $17.39 \mathrm{a}$ \\
\hline $\mathrm{K} 3 \mathrm{~F} 2$ & 42.93 & 78.03 & 4633.50 & $32.78 \mathrm{~b}$ & $12.63 \mathrm{bc}$ \\
\hline F hitung & 2.68 & 1.46 & 1.52 & 5.18 & 4.88 \\
\hline F tabel & 4.10 & 4.10 & 4.10 & 4.10 & 4.10 \\
\hline $\mathrm{CV}(\%)$ & 9.96 & 19.53 & 23.08 & 19.97 & 10.57 \\
\hline
\end{tabular}

Keterangan : Pada masing-masing variabel dan perlakuan, angka-angka dalam kolom yang sama diikuti huruf yang berbeda menunjukkan berbeda nyata pada uji DMRT $\alpha=0.05$ dan ${ }^{\mathrm{nb}}$ Transformasi akar $=$ $\sqrt{X+0.5}$

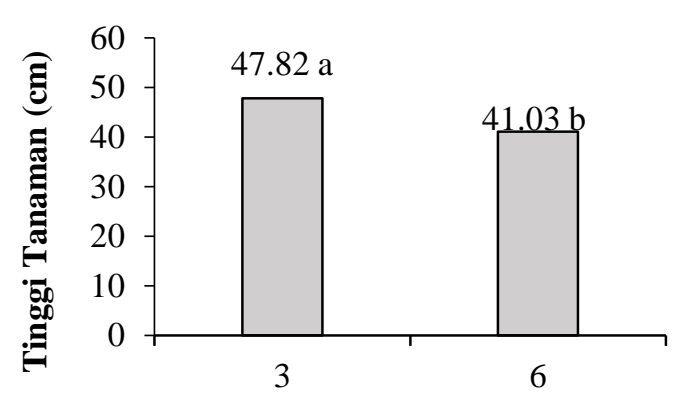

Waktu Pemberian Larutan Nutrisi (Hari)

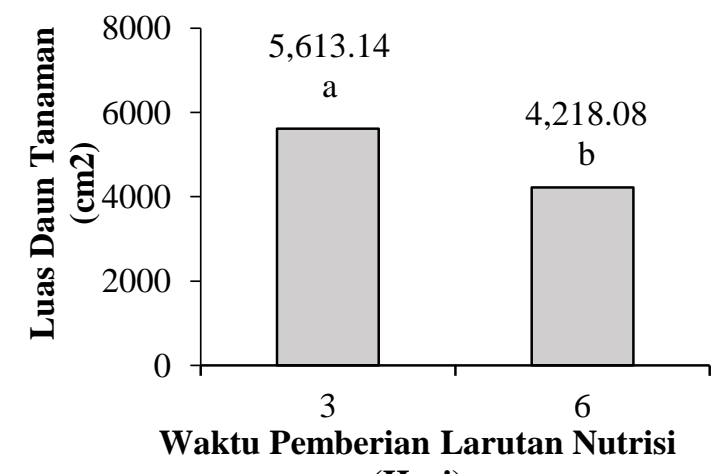

(Hari)

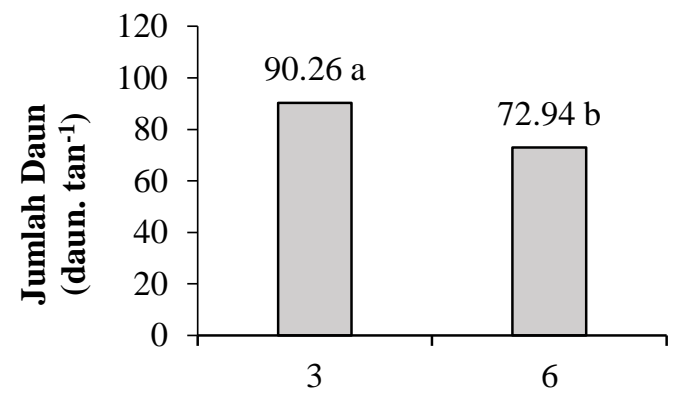

Waktu Pemberian Larutan Nutrisi (Hari)

\$ Bobot Tanaman Segar $\square$ Bobot Tanaman Kering

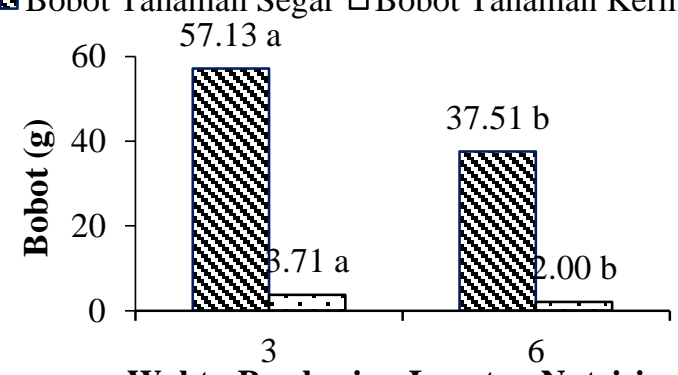

Waktu Pemberian Larutan Nutrisi (Hari)

Gambar 4. Respon pertumbuhan tanaman kentang pada waktu pemberian nutrisi Sundstrom. 
Tabel 3. Variabel pertumbuhan dan hasil tanaman kentang diberbagai ketebalan media cocopeat dan waktu pemberian nutrisi Sundstrom

\begin{tabular}{|c|c|c|c|c|c|c|}
\hline \multirow{3}{*}{ Perlakuan } & \multicolumn{6}{|c|}{ Variabel Pengamatan } \\
\hline & $\begin{array}{c}\text { Jumlah Umbi } \\
\text { Per Petak } \\
\text { Efektif } \\
\left(\mathbf{k n o l} / \mathbf{m}^{2}\right)\end{array}$ & $\begin{array}{l}\text { Efektivitas } \\
\text { Stolon (\%) }\end{array}$ & $\begin{array}{c}\text { Bobot } \\
\text { Tanaman } \\
\text { Segar }(g)\end{array}$ & $\begin{array}{c}\text { Bobot } \\
\text { Tanaman } \\
\text { Kering (g) }\end{array}$ & $\begin{array}{c}\text { Bobot } \\
\text { Umbi } \\
\text { Segar }(g)\end{array}$ & $\begin{array}{c}\text { Bobot } \\
\text { Umbi } \\
\text { Kering (g) }\end{array}$ \\
\hline & \multicolumn{6}{|c|}{ Ketebalan Media } \\
\hline K1 & 121.33 & 49.20 & 45.29 & 2.59 & 102.39 & 16.32 \\
\hline $\mathrm{K} 2$ & 85.33 & 38.98 & 47.39 & 2.72 & 113.46 & 17.82 \\
\hline $\mathrm{K} 3$ & 115.00 & 48.16 & 49.28 & 3.25 & 129.01 & 20.35 \\
\hline F hitung & 1.32 & 2.95 & 0.09 & 0.46 & 0.59 & 0.67 \\
\hline F tabel & 4.10 & 4.10 & 4.10 & 4.10 & 4.10 & 4.10 \\
\hline $\mathrm{CV}(\%)$ & $16.06^{\mathrm{nb}}$ & 17.64 & $17.08^{\mathrm{nb}}$ & $17.39^{\mathrm{nb}}$ & $17.92^{\mathrm{nb}}$ & $15.80^{\mathrm{nb}}$ \\
\hline \multicolumn{7}{|c|}{ Frekuensi Pemberian Nutrisi } \\
\hline F1 & 121.33 & $49.84 \mathrm{a}$ & $57.13 \mathrm{a}$ & $3.71 \mathrm{a}$ & $137.85 \mathrm{a}$ & $21.55 \mathrm{a}$ \\
\hline $\mathrm{F} 2$ & 93.11 & $41.04 \mathrm{~b}$ & $37.51 \mathrm{~b}$ & $2.00 \mathrm{~b}$ & $92.06 \mathrm{~b}$ & $14.77 \mathrm{~b}$ \\
\hline F hitung & 2.14 & 5.42 & 7.11 & 8.19 & 5.22 & 5.54 \\
\hline F tabel & 4.96 & 4.96 & 4.96 & 4.96 & 4.96 & 4.96 \\
\hline $\mathrm{CV}(\%)$ & $16.06^{\mathrm{nb}}$ & 17.64 & $17.08^{\mathrm{nb}}$ & $17.39^{\mathrm{nb}}$ & $17.92^{\mathrm{nb}}$ & $15.80^{\mathrm{nb}}$ \\
\hline \multicolumn{7}{|c|}{ Kombinasi Perlakuan Ketebalan Media dan Frekuensi Pemberian Nutrisi } \\
\hline K1F1 & 106.67 & 47.76 & 49.37 & 2.62 & 100.56 & 16.35 \\
\hline $\mathrm{K} 1 \mathrm{~F} 2$ & 136.00 & 50.64 & 41.21 & 2.56 & 104.23 & 16.29 \\
\hline $\mathrm{K} 2 \mathrm{~F} 1$ & 113.33 & 47.98 & 56.86 & 3.86 & 150.92 & 22.99 \\
\hline $\mathrm{K} 2 \mathrm{~F} 2$ & 57.33 & 29.97 & 37.92 & 1.59 & 76.01 & 12.65 \\
\hline $\mathrm{K} 3 \mathrm{~F} 1$ & 144.00 & 53.79 & 65.15 & 4.64 & 162.08 & 25.31 \\
\hline $\mathrm{K} 3 \mathrm{~F} 2$ & 86.00 & 42.52 & 33.41 & 1.86 & 95.93 & 15.39 \\
\hline F hitung & 2.23 & 2.65 & 0.86 & 1.97 & 1.54 & 1.36 \\
\hline F tabel & 4.10 & 4.10 & 4.10 & 4.10 & 4.10 & 4.10 \\
\hline $\mathrm{CV}(\%)$ & $16.06^{\mathrm{nb}}$ & 17.64 & $17.08^{\mathrm{nb}}$ & $17.39^{\mathrm{nb}}$ & $17.92^{\mathrm{nb}}$ & $15.80^{\mathrm{nb}}$ \\
\hline
\end{tabular}

Keterangan : Pada masing-masing variabel dan perlakuan, angka-angka dalam kolom yang sama diikuti huruf yang berbeda menunjukkan berbeda nyata pada uji DMRT $\alpha=0.05$ dan ${ }^{n b}$ Transformasi akar $=$ $\sqrt{X+0.5}$

Pertumbuhan Tanaman Kentang pada Kombinasi Ketebalan Media Cocopeat dengan Waktu Pemberian Nutrisi Sundstrom

Kombinasi ketebalan media steril cocopeat dan waktu pemberian larutan nutrisi Sundstrom berpengaruh nyata terhadap panjang akar dan jumlah akar. Gambar 5 menunjukkan waktu pemberian nutrisi 3 hari sekali memberikan pengaruh linear positif pada panjang akar dengan $\mathrm{R}^{2}=$ 0.88 dan jumlah akar dengan $\mathrm{R}^{2}=0.80$. Waktu pemberian nutrisi 6 hari sekali memberikan pengaruh linear positif pada panjang akar dengan $\mathrm{R}^{2}=0.94$ karena dengan waktu pemberian nutrisi 3 hari sekali menunjukkan peningkatan pertumbuhan jumlah akar dengan semakin tebal media tanamnya dan linear negatif pada jumlah akar dengan $\mathrm{R}^{2}=0.82$ karena terjadi penurunan pertumbuhan jumlah akar pada perlakuan pemberian nutrisi 6 hari sekali dengan semakin tebal media tanamnya. Tabel 2 menunjukkan bahwa ketebalan media $20 \mathrm{~cm}$ dan pemberian nutrisi 3 hari sekali memberikan panjang akar dan jumlah akar terbaik yaitu $17.34 \mathrm{~cm}$ dan 48.67 akar. 


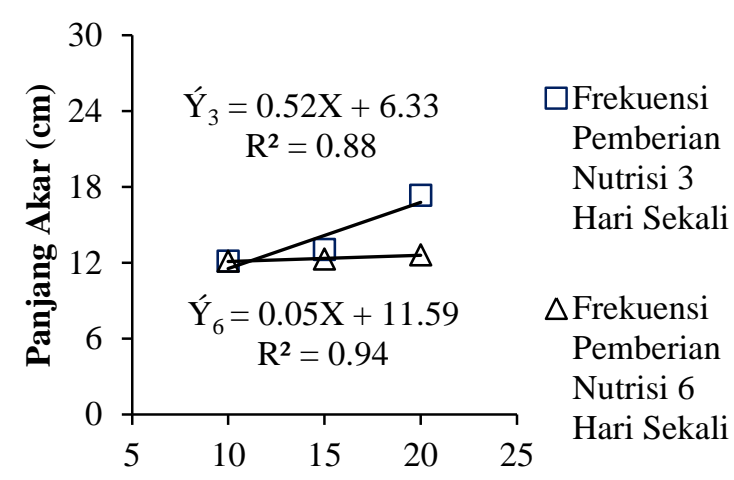

Ketebalan Media (cm)

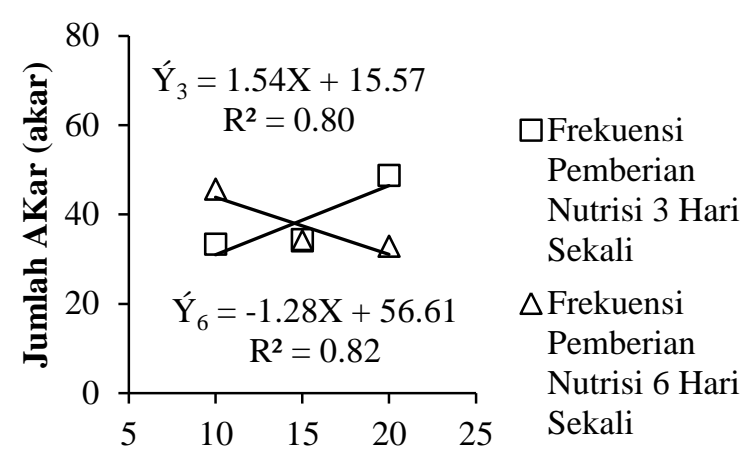

Ketebalan Media (cm)

Gambar 5. Panjang akar jumlah akar tanaman kentang pada kombinasi ketebalan media steril cocopeat dengan waktu pemberian larutan nutrisi Sundstrom.

Ketebalan media yang semakin tinggi memperlihatkan kebutuhan hara yang harus ditingkatkan (Gambar 8 dan 9). Pemberian nutrisi harus lebih sering pada ketebalan media yang semakin tinggi. Menurut Ginting (2009) bahwa semakin tebal media tanam maka akan semakin meningkatkan panjang akar dan berat akar dan semakin tebal media tanam akan membutuhkan hara dan air yang lebih banyak oleh karena itu perlu manajemen pemberian air dan larutan nutrisi yang baik sehingga pertumbuhan tanaman

\section{KESIMPULAN}

Perlakuan ketebalan media steril cocopeat $20 \mathrm{~cm}$ mampu memberikan pertumbuhan yang lebih baik dibandingkan dengan perlakuan ketebalan media yang lainnya. Waktu pemberian nutrisi 3 hari sekali mampu memberikan pertumbuhan yang baik dan bobot umbi yang lebih baik dibandingkan dengan pemberian nutrisi 6 hari sekali. Terjadi interaksi pada perlakuan akan tetap terjaga. Pemberian nutrisi yang semakin sering (3 hari sekali) mampu menyediakan unsur hara yang dibutuhkan untuk pertumbuhan akar. Kandungan fosfor dan kalsium dalam nutrisi Sundstrom dibutuhkan tanaman untuk pertumbuhan akar. Fosfor berperan dalam menstimulir pertumbuhan akar, sedangkan $\mathrm{Ca}$ dapat mempengaruhi bagian meristem akar, yang akan mempengaruhi pertumbuhan dan pemanjangan, juga pembesaran sel (Haris, 2010).

\section{DAFTAR PUSTAKA}

Alwi, M., N. Fauziati, dan Nurita. 2008. Serapan Hara dan Pertumbuhan Mentimun, Lobak, serta Sawi Pada Kadar Air Tanah Gambut Yang Berbeda. Balai Penelitian Pertanian Lahan Rawa. Banjarbaru. Kalimantan Selatan. ketebalan media cocopeat dengan waktu pemberian nutrisi terhadap pertumbuhan jumlah akar dan panjang akar tanaman kentang. Pada penelitian ini, perlakuan ketebalan media cocopeat dan waktu pemberian nutrisi belum mampu memberikan peningkatan jumlah produksi umbi mini kentang (G0).

Badan Pusat Statistik. 2014. Luas Panen, Produksi dan Produktivitas Kentang, 2009-2013. Badan Pusat Statistik Republik Indonesia. Jakarta.

El-Latif, K.M.A., Osman, E.A.M., Abdullah, R., and el Kader, N.A. 2011. Response of potato plants to potassium fertilizer rates and soil moisture deficit. 
Advances in Applied Science Research $2 \quad$ (2): 388-397.

http://www.imedpub.com/articles/respo nse-of-potato-plants-to-potassiumfertilizer-rates-and-soil-moisturedeficit.pdf.

Ginting, C. S. 2009. Pengaruh Ketebalan Media Pasir Terhadap Pertumbuhan dan Kualitas Aksesi Rumput Bermuda (Cynodon dactylon L.). Skripsi. Program Studi Hortikultura Fakultas Pertanian. Institut Pertanian Bogor. Bogor.

Ginting, C. dan T. C. Rakian. 2008. Hidroponik : Pertanian Masa Depan Untuk Masyarakat Perkotaan. WartaWiptek. Vol 16: Hal. 1-6.

Haris. 2010. Pertumbuhan dan Produksi Kentang Pada Berbagai Dosis Pemupukan. J. Agrisistem. Vol 6 (1): Hal. 15-22.

Kenneth F. K. dan K. C. Ornelas. 2012. World History of Food. Cambridge University Press.

Kristijono, A. 2010. Pemanfaatan Gambut Sebagai Media Tumbuh BITUMAN (Biji Tumbuh Mandiri) Dalam Rangka Mendukung Rehabilitasi Lahan Kritis. Laporan Penelitian. Pusat Teknologi Pengelolaan Sumber Daya lahan, Wilayah, dan Mitigasi Bencana. Badan Pengkajian dan Penerapan Teknologi. Jakarta.

Mobini, S.H., M. R. Ismail, H. Arouiee. 2015. The impact of aeration on potato (Solanum tuberosum L.) minituber production under soilless condition. African Journal of Biotechnology 14 (11): 910-921. Doi: 10.5897/AJB09.111.

Napitupulu, D. dan L. Winarto. 2010. Pengaruh Pemberian Pupuk N dan K Terhadap Pertumbuhan dan Produksi
Bawang Merah. J. Horti. Vol 20 (1): 27-35.

Prahardini, P. E. R., A. G. Pratomo, Harwanto, dan Wahyunindyawati. 2008. Pengkajian Perbenihan Kentang Di Kabupaten Lumajang Jawa Timur. Dalam: W. W. Hadisoeganda, A. A. Asandhi, A. S. Duriat, N. Gunadi, L. Prabaningrum, E. Sofiari, R. S. Basuki, N. Nurtika, dan A. K. Karyadi (Eds.), Prosiding Seminar Nasional Pekan Kentang 2008. 20-21 Agustus. Lembang. 1-14.

Ramírez, D.A., Yactayo, W., Gutiérrez, R., Mares, V., De Mendiburu, F., Posadas, A., Quiroz, R. 2014. Chlorophyll concentration in leaves is an indicator of potato tuber yield in water-shortage conditions. Scientia Horticulturae 168: 202-209.

DOI: https://doi.org/10.1016/j.scienta.2014.0 1.036 .

Resh, H. M. 2004. Hydroponic Food Production, 6th ed. New Concept Press Publishing Co., Mahwah, NJ.

Sayaka, B. dan J. Hestina. 2011. Kendala Adobsi Benih Bersertifikat Untuk Usaha Tani Kentang. Jurnal Agro Ekonomi Vol 2 (1): 27-41.

Schuzle, E. D. and M. M. Cadwell. 1995. Ecophysiology of Photosinthesis. Springerverlag Berlin Heidelberg. Germany. 576p.

Suwarno, W. B. 2008. Sistem Perbenihan Kentang di Indonesia. http://www.situshijau.co.id. Diakses Maret 2015.

Wasonowati, C. 2011. Meningkatkan Pertumbuhan Tanaman Tomat (Lycopersicon esculentum) dengan Sistem Budidaya Hidroponik. Jurnal Agrovigor. Vol 4 (1): 21-28. 
Zamzami, A., R. Rogomulyo., S. Purwanti. 2016. Pengaruh Waktu Pemupukan dan Macam Pupuk Kandang terhadap Pertumbuhan dan Hasil Kedelai Hitam (Glycine max (L.) Merrill). Vegetalika 5 (1): 13-22.

Zelalem, A., T. Tekalign, dan D. Nigussie. 2009. Response of potato (Solanum tuberosum L.) to different rates of nitrogen and phosphorus fertilization on vertisols at Debre Berhan, in the central highlands of Ethiopia, Afr. $J$. Pl. Sci., Vol. (3)2:16-24.

Zelelew, D.Z., S. Lal, T.T. Kidane, and M.G. Biniam. 2016. Effect of Potassium Levels on Growth and Productivity of Potato Varieties. American Journal of Plant Sciences 7: 1629-1638. http://dx.doi.org/10.4236/ajps.2016.712 $\underline{154}$ 